\author{
ЦИФРОВІЗАЦІЯ ОСВІТИ ЯК СУЧАСНА ТЕНДЕНЦІЯ \\ ПРОФЕСІЙНОЇ ПІДГОТОВКИ БАКАЛАВРІВ ІЗ БІЗНЕС-ЕКОНОМІКИ \\ У КИТАЙСЬКІЙ НАРОДНІЙ РЕСПУБЛІЦІ \\ DIGITALIZATION OF EDUCATION AS A MODERN TENDENCY \\ OF PROFESSIONAL TRAINING OF BACHELORS \\ OF BUSINESS ECONOMICS IN CHINA
}

УДК 378.147

DOI https://doi.org/10.32843/2663-

6085/2019.21.3-43

\section{Гао Ванчуен,}

директор кафедри англійської мови, викладач англійської мови

Цзясінського університету

\section{цицюра К.В.,}

аспірант

Інституту професійно-технічної освіти Національної академії педагогічних наук України,

іноземний експерт

Цзясінського університету

\section{Романова Г.М.,}

докт. пед. наук, професор кафедри

профресійної та вищої освіти

Центрального інституту

післядипломної освіти

Університету менеджменту освіти
Системний характер соціально-економічної кризи в 90-х роках ХХ століття в Україні став причиною виникнення кризи у вищій школі. Ця криза супроводжується втратою викладацьких кадрів, руйнуванням матеріально-технічної бази вищої школи, поверхневим характером реформ університетської освіти і зниженням якості освіти загалом. У XXI столітmі відбулися істотні зміни в освіті, зокрема глобалізація, яка поступово призвела до зростання академічної мобільності, уніфрікації навчальних планів і методів навчання, широкого розповсюдження дистанційної освіти. В умовах, які склалися, головним завданням сучасної освіти є застосування нових інорормаційних технологій $i$ новітніх тенденцій у поширенні знань, для того щоб підготувати майбутніх випускників до самостійного вирішення нетипових завдань, пошуку інфрормації, постійного оволодіння новими знаннями. Тому дослідження цифровізації як тенденції професійної підготовки спеціалістів у Китайській Народній Республіці для майбутньої орієнтації української освіти на зарубіжний досвід є досить актуальною темою в сфрері розвитку освітнього процесу в нашій країні.

метою цієї статті $є$ охарактеризувати цисрровізацію як сучасну тенденцію професійної підготовки майбутніх бакалаврів із бізнес-економіки на прикладі державного універcumemу в Китайській Народній Республіці.

у статті цифровізація виокремлена та охарактеризована як одна з основних сучасних тендениій профресійної підготовки майбутніх бакалаврів із бізнес-економіки у вищих навчальних закладах на прикладі китайського університету. Позитивні особливості розвитку професійної компетентності майбутніх бакалаврів із бізнесекономіки в Китайській Народній Республіці виявлені в результаті застосування цифрровізації як тенденції китайської освіти, а також зазначено можливість впровадження інфрормаційних технологій у вищу економічну освіту України. Доведено, що використання досвіду цифровізації профресійної підготовки майбутніх бакалаврів із бізнес-економіки в Китайській Народній Республіці може покращити сучасну економічну освіту в Україні. Ключові слова: економічна освіта, освітньо-профресійна програма, профресійна компетентність, циорровізація, інфрормаційні технології.
The systemic nature of the socio-economic crisis in the 1990s in Ukraine caused the crisis in higher education. This crisis is accompanied by the loss of teaching staff, the destruction of the higher education material and technical base, the superficial nature of university education reforms, and, as a consequence, the decline in the quality of education as a whole.

However, significant changes in education have happened in the 21st century. Globalization in education is gradually leading to the increased academic mobility, the unification of curricula and teaching methods, and the widespread adoption of distance education. In the current circumstances, the main task of modern education is the application of new information technologies and the latest tendencies in the knowledge sharing, in order to prepare future graduates to independently solve atypical problems, search for information, continuously master their new knowledge.

Thus, the study of digitalization as a tendency of professional training of specialists in People's Republic of China in the field of educational process development is a very relevant topic for the future orientation of Ukrainian education to the foreign experience. The aim of this article is to characterize digitalization as a modern tendency for the professional training of future bachelors of Business Economics using the example of a governmental university in the People's Republic of China.

Digitalization is highlighted and characterized as one of the main modern trends in the professional traning of future bachelors of Business Economics in higher education institutions using the example of a university in the People's Republic of China. Positive features of the professional competence development of the future bachelors of Business Economics in People's Republic of China are identified as a result of the application of digitalization as a tendency of Chinese education, as well as the possibility of introducing information technologies in higher economic education in Ukraine is considered. Using the experience of digitalization of the professional training of future bachelors of Business Economics in People's Republic of China has been proved to be the way to improve the current economic education in Ukraine.

Key words: economic education, educational and professional program, professional competence, digitalization, information technologies.
Постановка проблеми. Глобалізація в освіті призводить до зростання академічної мобільності, уніфікації навчальних планів і методів навчання, а також цисрровізації освіти. В умовах, які скла- лися, ключовим завданням освіти в XXI столітті $€$ застосування нових інорормаційних технологій у навчанні та викладанні. Процеси вищої освіти зумовлені ситуацією, яка склалася всередині 
90-х років минулого століття в Україні, а саме загальною соціально-економічною кризою, системний характер якої викликав і кризу вищої школи, що супроводжується поверхневим характером реформ університетської освіти, втратою викладацьких кадрів, зниженням якості освіти, розривом інформаційних зв'язків, руйнуванням матеріальнотехнічної бази вищої школи і стрімкою девальвацією статусу викладацької діяльності.

На сьогодні назріла реальна необхідність реформування системи вищої освіти в Україні. Це обумовлено багатьма об'єктивними обставинами. Викладання навчальних дисциплін у вищій школі має ставити за мету підготовку фахівця, знання і вміння якого повністю відповідають умовам сучасного інформаційного суспільства. Але відразу ж постає питання: чи можна цього досягти, використовуючи застарілі підходи і методи?

Перед сучасною системою освіти постають такі виклики: навчити студента самостійно вирішувати нетипові завдання, вести пошук інфрормації, постійно оволодівати новими знаннями, а для цього необхідні інноваційні підходи. На жаль, випускники закладу вищої освіти, отримавши відповідний диплом, часто ще не готові до роботи за обраною спеціальністю. Це багато в чому обумовлено саме якістю навчання, рівнем засвоєних кожним студентом знань та вмінь, великими прогалинами в контролі за навчальною діяльністю студента та кінцевими результатами.

Аналіз останніх досліджень і публікацій. Аналіз нормативних документів щодо цифровізації освіти дозволяє виокремити європейську стратегію економічного розвитку «Європа-2020: стратегія розумного, сталого і всеосяжного зростання», яка стала основою проекту «Цифровий порядок денний України 2020». Цей проект, представлений Кабінетом Міністрів України, визначає базові пріоритетні позиції розвитку інорормаційного суспільства в Україні, засновані на інтеграції у світові процеси цифровізації [5].

Впровадження інформаційно-комунікаційних технологій у життя сучасного суспільства зумовило інтерес зарубіжних і вітчизняних науковців до наукового осмислення цифровізації як тенденції підготовки майбутніх спеціалістів. Проблемою модернізації та реформування вищої освіти 3 використанням інфрормаційних технологій опікувалися такі зарубіжні та вітчизняні науковці: Т. Вакалюк, А. Данилицька, М. Жалдак, О. Михайленко, І. Роберт, М. Шишкіна. Особливості розвитку сучасних інформаційно-комунікативних технологій і поняття цифровізації досліджували у своїх працях В. Биков, Д. Галкін, Г. Крибер, М. Лещенко, П. Матюшко, О. Овчарук, П. Самуельсон, Д. Тапскотт та інші.

Виокремлення не вирішених раніше частин загальної проблеми. Незважаючи на те, що нормативно-правові документи обґрунтовують і роз'яснюють перспективні напрями цифровізації різних сорер життя, деякі аспекти досі потребують досконалого вивчення, зокрема недостатньо вивчено зарубіжний досвід щодо особливостей цифровізації освітнього процесу у закладах вищої освіти. Саме тому дослідження цифровізації вищої освіти в Китайській Народній Республіці, зокрема економічної, для майбутньої орієнтації української освіти на зарубіжний досвід є досить актуальною темою в сорері розвитку освітнього процесу України.

Метою статті $є$ охарактеризувати цисровізацію як сучасну тенденцію професійної підготовки майбутніх бакалаврів-економістів на прикладі державного університету в Китайській Народній Республіці.

Методи, які використовувалися авторами під час дослідження:

- теоретичні: аналіз (для дослідження освітньо-профресійної програми Китайського університету та виокремлення цифровізації як однієї з основних тенденцій підготовки майбутніх бакалаврів зі спеціальності «Бізнес-економіка» у вищих навчальних закладах Китаю), порівняння (для виявлення позитивних рис фрормування професійної компетентності майбутніх бакалаврів із бізнес-економіки Китаю), узагальнення (для фрормулювання висновків і рекомендацій щодо застосування цифровізації освіти як тенденції профресійної підготовки бакалаврів 3 «Бізнес-економіки» Китайської Народної Республіки у вітчизняній освіті).

- емпіричні: обсерваційні (пряме спостереження цифровізації професійної підготовки бакалаврів під час навчального процесу в державному університеті Китайської Народної Республіки) для дослідження цифровізації підготовки бакалаврів за спеціальністю «Бізнес-економіка» в китайському університеті.

Виклад основного матеріалу. Зміст поняття «цифровізація» розглядається вченими як трансфрормування інформації у цифррову фрорму, а також комплексне вирішення управлінського, інфрраструктурного, культурного та поведінкового характеру [1, с. 1-14]. Саме тому можна дійти висновку, що основними технологіями цифровізації є розвиток технологій інтернету та мобільних комунікацій.

Система освіти України ще недостатньо «розігналася» на шляху до цифрової перебудови, про це свідчать і роботи іноземних дослідників [7, с. 18-26; 8]. У будь-якій освітній організації $€$ певний відсоток викладачів, які досить рідко використовують електронні освітні ресурси та інфрормаційно-комунікаційні технології або не використовують їх зовсім, хоча епоха їх активного впровадження закінчилася більш ніж десять років тому. Процес цифровізації є непростим перш за 
все з ресурсної та методичної точок зору. Західний підхід, згідно з яким викладач створює ресурси, а його помічник «упроваджує» їх в інорормаційне середовище навчального закладу, навряд чи може бути ефективно реалізований у найближчому майбутньому. Разом із цим українські заклади вищої освіти прагнуть до впровадження цифрових технологій у навчальний процес, незважаючи на труднощі фрінансового та технологічного характеру, але рівень циоррового університету для більшості закладів вищої освіти ще довго буде недосяжним.

3 огляду на це орієнтація на зарубіжний досвід цифровізації освітнього процесу у закладах вищої освіти $€$ необхідною та актуальною, зокрема й досвід Китайської Народної Республіки. Автори розглядають циорровізацію освітнього процесу як тенденцію профресійної підготовки на прикладі бакалаврів із бізнес-економіки класичного державного університету Китайської Народної Республіки - Цзясінського університету (Jiaxing University), який знаходиться в місті Цзясін провінції Чжецзян.

Освітньо-профресійна програма спеціальності «Бізнес-економіка» Цзясінського університету (Jiaxing University) передбачає підготовку майбутніх бакалаврів 3 обов'язковим використанням інформаційних технологій. Переваги цифрової освіти з'являються тоді, коли студент мотивований, знає, чого хоче від освіти, здатний до самоорганізації та само-освіти, вміє адекватно оцінювати себе, диференціювати ресурси і інорормацію (це повинно бути сорормовано в школі і далі підтримуватися в закладах вищої освіти). На фрормуванні саме таких навичок та вмінь і наголошує програма [3].

Згідно 3 освітньо-професійною програмою бакалаврів із бізнес-економіки, основними фраховими або предметно-спеціальними компетентностями, пов'язаними з сучасними інфрормаційними технологіями, є такі:

- мати міцну теоретичну підготовку в сорері міжнародної бізнес-економіки та торгівлі, а також навички роботи в офролайн / онлайн продажах, навички управління міжнародним бізнесом;

- вміти використовувати сучасні інфрормаційні технології інтернету для управління міжнародними торговими підприємствами, розуміти способи виконання операцій і процедури транзакцій у міжнародній електронній комерції,

- оволодіти основними технологіями і навичками використання мобільних і комп'ютерних додатків електронної комерції та їх управління;

- вміти опрацьовувати, аналізувати та вирішувати на основі великих баз даних у питаннях глобальної торгівлі та управління міжнародним бізнесом [3, с. 877-894].

У вітчизняному та зарубіжному науковому та освітньому середовищах активно запроваджу- ється змішане навчання, яке поєднує традиційне очне і онлайн- та офрдлайн-навчання [4]. Ця технологія також активно використовується викладачами університетів Китайської Народної Республіки на економічних спеціальностях для курсів підготовки до екзаменів взагалі та міжнародних екзаменів 3 англійської мови зокрема. Викладачі Цзясінського університету (Jiaxing University) спеціальності «Бізнес-економіка» активно користуються інорормаційно-освітнім середовищем університету для реалізації взаємодії зі студентами-економістами у процесі їх підготовки до екзаменів. Для цього вони використовують мобільні додатки та їх версії для комп'ютерів і ноутбуків. Одним із найкращих і досить фрункціональних додатків $є$ китайська розробка WeChat.

WeChat - це мобільний додаток, який також має версію для комп'ютерів і ноутбуків, що використовується не тільки для спілкування, а також і для навчання [2]. WeChat $€$ одним 3 освітніх ресурсів, рекомендованих розробниками «Педагогічного колеса 5.0», яке поєднує 188 різних мобільних додатків, що можуть бути використані студентами для створення, запам'ятовування, оцінки, аналізу інорормації [6]. Такі мобільні платформи допомагають студентам шукати, збирати, категоризувати, порівнювати, представляти та підсумовувати необхідну інорормацію для навчання, а також ділитися нею з одногрупниками та викладачами. Зокрема фрункціонал WeChat надає студентам і викладачам можливість створювати групові чати, в яких можна ділитися текстовими та голосовими повідомленнями, відео- та аудіо-записами, посиланнями на веб-сайти, а також створювати онлайн-конференції [2].

Наприклад, курси підготовки до екзаменів включають теоретичний і практичний матеріал. Теоретичний матеріал може бути записаний викладачем у відео- або аудіо-орорматі або у фрорматі презентації Microsoft Office Power Point і відправлений до чату кожної групи студентів у мобільному додатку WeChat, що дозволяє їм вивчати теоретичний матеріал у зручний час, використовуючи індивідуальний темп. Домашнє завдання може бути відправлено викладачем у фрорматі текстового або голосового повідомлення 3 можливістю повторного прослуховування, щоб надати можливість студентам завжди мати всі завдання та пояснення під рукою. Потім, коли теоретичний матеріал вивчено всіма студентами, на аудиторних практичних заняттях із підготовки до міжнародних екзаменів можуть бути відпрацьовані необхідні навички, оперативно внесені корективи. Також на занятті обговорюються труднощі, які виникли в процесі самостійної роботи. За характером проблематики, яка зацікавила або викликала труднощі у студентів бізнес-економіки під час домашньої підготовки, в аудиторії фрормуються малі навчальні групи, 
що дозволяють індивідуалізувати підхід до студентів різних рівнів і прискорити засвоєння ними навчального матеріалу.

Для майбутнього бакалавра з бізнес-економіки важливо, щоб цифровізація освіти та його діяльності економіста стала ефективним інструментом, який не ускладнює його життя в профресії, а полегшує його, не знижує комунікативні вміння, а розширює їх, дозволяючи активізувати їх у процесі економічної діяльності. За результатами аналізу особливостей цифровізації освітнього процесу в закладах вищої освіти Китайської Народної Республіки можна зробити висновок, що цифрові технології надають ряд нових можливостей як для викладачів, так і для студентів. 3 огляду на це перед закладами вищої освіти України можуть бути поставлені такі завдання цифровізації:

- активне впровадження та використання інформаційних технологій в освітньому процесі;

- забезпечення підвищення мотивації викладачів і студентів до професійного використання інорормаційних технологій;

- забезпечення навчання та підвищення кваліфрікації професорсько-викладацького складу закладів вищої освіти щодо використання цифрових технологій в освітній діяльності;

- надання професійних інфрормаційних і консультаційних послуг щодо використання циоррових і хмарних технологій;

- надання можливості викладачам разом користуватися інформаційними ресурсами і мати вільний доступ до них;

- створення інноваційних умов навчання та викладання завдяки впровадженню цифрових технологій в освітній процесс.

Якщо система вищої освіти виконає ці завдання, вона зможе забезпечити суспільству впевнений перехід до цифрової епохи, спрямований на підвищення рівня ефективності освітнього процесу та індивідуалізацію навчання.

Висновки. Вивчення авторами зарубіжного досвіду щодо циоровізації освітнього процесу в університетах Китайської Народної Республіки на прикладі спеціальності «Бізнес-економіка» дозволяє зробити висновок про те, що цисровий складник процесу освіти фрормує та розвиває у майбутнього економіста вміння та навички цифрової комунікації, роботи в інфрормаційному освітньому середовищі і з цифровими пристроями та освітніми ресурсами, здатність до постійної самоосвіти і профресійного саморозвитку, а також дає змогу здобути освіту відповідно до інтересів і потреб студентів. Цифрровізація є однією з основних сучасних тенденцій підготовки майбутніх бакалаврів із бізнес-економіки у закладах вищої освіти в Китайській Народній Республіці. Результатом застосування цифровізації як тенденції китайської освіти $€$ ефрективне формування професійної компетентності майбутніх бакалаврів із бізнес-економіки Китаю.

Перспектива полягає у подальшому дослідженні можливостей мобільних додатків і платформ для дистанційного та змішаного навчання та умов їх використання в умовах фрорс-мажору. Використання досвіду цифровізації профресійної підготовки майбутніх бакалаврів із бізнес-економіки Китайської Народної Республіки може значно покращити сучасну економічну освіту в Україні.

\section{БІБЛІОГРАФІЧНИЙ СПИСОК:}

1. Гаврілова Л.Г., Топольник Я.В. Циоррова культура, цифрова грамотність, цифрова компетентність як сучасні освітні френомени. Інформаційні технології і засоби навчання. 2017. № 5. Том 61. С. 1-14.

2. Олейник А. Один за всех: как WeChat решил все мобильные потребности китайцев. URL: https://ain.ua/special/wechat-veon/ (дата звернення: 29.01.2020).

3. Освітньо-профресійна програма для ступеня бакалавра, 2018. Цзясін : Видавництво академічного оорісу Цзясінського університету, 2018. 942 с.

4. Технологии электронного обучения [Электронный ресурс] : учебное пособие. А.В. Гураков [и др.]. Томский государственный университет систем управления и радиоэлектроники. Электрон. текстовые данные. Томск, 2016. 68 c. URL: http:www. iprbookshop.ru/72196.html (дата звернення: 27.01.2020).

5. Цифрова адженда України - 2020. URL: https://ucci.org.ua/uploads/files/58e78ee3c3922.pdf (дата звернення: 28.01.2020).

6. Allan Carrington. The Padagogy Wheel English, version 5.0. URL: https://designingoutcomes. com/english-speaking-world-v5-0/ (дата звернення: 09.02.2020).

7. Gikas J., Grant M. Mobile computing devices in higher education: Student perspectives on learning with cellphones, smartphones \& social media. The Internet and Higher Education. 2013. № 19. P. 18-26.

8. Newman D. Top 6 digital transformation trends in education. URL: www.forbes.com/sites/danielnewman (дата звернення: 27.01.2020). 